\title{
Effect of food components and processing parameters on DNA degradation in food
}

\author{
Torsten BAUER ${ }^{1}$, Walter P. HAMMES ${ }^{1}$, Norbert U. HAASE ${ }^{2}$ and Christian HERTEL ${ }^{1 \text { * }}$ \\ ${ }^{1}$ Institute of Food Technology, University of Hohenheim, 70593 Stuttgart, Germany \\ ${ }^{2}$ Federal Centre for Cereal, Potato and Lipid Research, 32765 Detmold, Germany
}

The effect of food components on degradation of DNA by DNase I (EC 3.1.21.1) was monitored by electrotransformation of Escherichia coli, making it possible to determine the number of plasmid molecules capable of giving rise to transformed cells. The transformation frequency increased linearly with the plasmid number within the range of $2 \times 10^{6}$ to $2 \times 10^{10}$. DNA degradation was reduced by one order of magnitude in the presence of $0.05 \%\left(w . v^{-1}\right)$ maltol or $1 \mathrm{mM}$ putrescine. Complete inhibition of degradation was observed with $\geq 0.2 \%\left(w^{-1} \mathrm{v}^{-1}\right)$ maltol, $\geq 0.01 \%\left(\mathrm{w} . \mathrm{v}^{-1}\right)$ octyl gallate or $\geq 0.5 \mathrm{mM}$ of spermine. To monitor degradation of plant DNA during food processing, a real-time PCR system was established. The ratio of copy numbers of a potato gbss DNA fragment of $325 \mathrm{bp}$ and a nested $96 \mathrm{bp}$ fragment was determined. The latter served as internal reference for normalization. The system made it possible to exclude process-dependent changes of DNA concentration in the food matrix. Processing of genetically modified potatoes to dried potato sticks, crisps or flakes was studied and drying steps were shown to exert the strongest effect on DNA degradation, resulting in a drop of the ratio from 0.73 to 0.16 .

Keywords: food processing / food components / potato / DNA stability / real-time PCR

\section{INTRODUCTION}

The safety assessment of genetically modified (GM) plants requires a holistic approach to identify and characterize hazards that are associated with the genetic modification. As part of this approach, the likelihood of transfer of recombinant plant DNA to bacteria and its potential impact are of special interest (Codex Alimentarius Commission, 2003a, 2003b; FAO/WHO, 2000). To apply the principle of risk assessment (Codex Alimentarius Commission, 1999, 2003b; Lammerding, 1997), one has to bear in mind that horizontal gene transfer from GM plants to bacteria takes place by transformation only. Therefore, data are needed about competence development of bacteria in food, accessibility of DNA to the competent cells, frequencies of transformation, and degradation of DNA in food. It has been shown that food associated bacteria can acquire natural competence during growth and/ or become naturally transformed in foods, e.g. Bacillus subtilis (Bräutigam et al., 1997; Kharazmi et al., 2002; Wittke et al., 2002; Zenz et al., 1998), Escherichia coli
(Bauer et al., 1999), Streptococcus gordonii (Kharazmi et al., 2003b). Moreover, transfer of recombinant plant DNA to food-associated bacteria was detected, at least under optimal laboratory conditions (Kharazmi et al., 2003a). It was observed that to obtain measurable events, homologous sequences present in the DNA of the GMplant and bacterium are required. Furthermore, such homologous sequences may facilitate co-transfer of nonhomologous foreign DNA (De Vries et al., 2001; De Vries and Wackernagel 2002; Gebhard and Smalla, 1998).

In the course of food processing, DNA is subjected to degradation, reducing the number of DNA molecules that are capable to give rise to a transformed cell (Jonas et al., 2001; Rizzi et al., 2003). As a consequence, the likelihood of transformation events can decrease to levels far below the limit of experimental detection (Kharazmi et al., 2003a). The extent of DNA degradation is affected by the conditions of food processing and storage, as well as the food matrix (Rizzi et al., 2003). Straub et al. (1999)

\footnotetext{
* Corresponding author: hertel@uni-hohenheim.de
} 
monitored the enzymatic degradation of plasmid DNA in summer sausages and observed protective effects of the meat matrix on DNA. Furthermore, adsorption of DNA onto particles such as clay (remnant of harvesting) can result in less susceptibility to degradation than in solution (Demaneche et al., 2001; England et al., 1998). Thus, interactions of food components with DNA may result in enhanced degradation or protection of DNA, however up to now only limited data on that process are available. Polyamines such as spermine were identified to exhibit protective effects on DNA against irradiation (Douki et al., 2000; Oh and Kim, 1998). Heat treatment and pH were identified as the main degrading parameters in food, with regard to processing condition (Bauer et al., 2003; Hupfer et al., 1998). Klein et al. (1998) monitored the degradation of DNA during production of sugar by spiking experiments, and determined the overall efficacy of DNA elimination in this process to $>10^{14}$. Gryson et al. (2002) showed that the degumming process during refining of soybean oil was crucial in removing DNA.

We investigated the effect of food components on the enzymatic degradation of DNA using a detection system based on electrotransformation of E. coli. This system made it possible to quantify functional DNA molecules that are capable to give rise to a transformed cell. Furthermore, we developed a monitoring system based on realtime PCR to determine independently of changes in the food matrix the extent of DNA degradation in different steps of processing. This monitoring system was used to investigate the degradation of plant DNA during processing of potato products.

\section{RESULTS}

\section{Effect of food components on DNA degradation}

To investigate the effect of food components on enzymatic degradation of DNA, a model system was established consisting of DNA of plasmid pSG100 and DNase I. Degradation was monitored by transformation of E. coli, making it possible to determine the number of plasmid molecules capable of giving rise to transformed cells. Therefore, the dependency of transformation frequency (TF) on the concentration of intact pSG100 molecules was investigated. The TF correlated linearly with the molecule concentration within the range of $2 \times 10^{6}$ to $2 \times 10^{10}$ molecules. $\mu 1^{-1}$ (Fig. 1). Use of lower concentrations in the assay resulted in numbers of $<30 \mathrm{CFU}$ per plate, which are statistically not relevant. At higher concentrations, the TF approached the maximum TF given

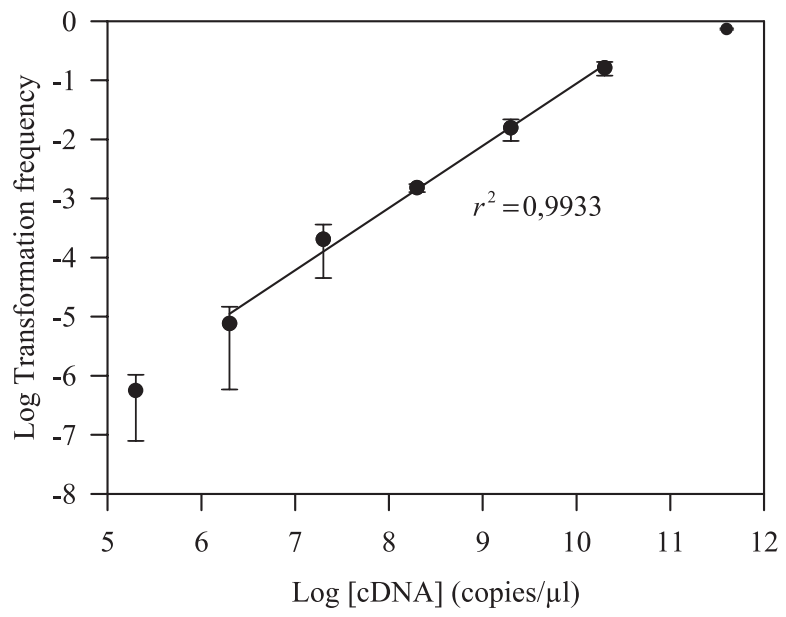

Figure 1. Dependency of the transformation frequency (TF) of $E$. coli XL1 on the concentration of molecules of plasmid pSG100. Error bars indicate standard deviations of at least 3 independent experiments.

by the maximum number of cells becoming electrocompetent. To determine the optimal incubation time with DNase I in the model, its effect on the reduction of TF over time was investigated. Within $30 \mathrm{~s}$, the TF rapidly decreased by $2.5 \operatorname{logs}$, down to approximately $10^{-5}$, and thereafter no further decrease was observed (Fig. 2). As the use of DNA linearized with PstI resulted in comparable low TFs, it can be assumed that within $30 \mathrm{~s}$, all plasmid molecules had become linearized by DNase I. However, within this time span, the determination of the $\mathrm{TF}$ is rather inaccurate, as it is indicated by the standard deviation. Moreover, monitoring the effect of food components on DNA degradation at $60 \mathrm{~s}$ also resulted in greatly varying TF values with standard errors of $c a .80 \%$ of the mean values (data not shown). Thus, to ensure that the monitoring of degradation is not susceptible to minor variations of DNase I activity or interactions between food component and plasmid DNA, we used a $2 \mathrm{~min}$ incubation time, leading to the reduction of the standard error to $c a$. $40 \%$ of the mean value.

The effect of numerous food components on the enzymatic degradation of plasmid DNA was investigated using the established model system. Out of 29 components, only maltol, octyl gallate, putrescine, and spermine affected DNA degradation, as compared to the control. No effect of the food components on the transformation event itself was observed. A concentration of only $0.05 \% \mathrm{w} \cdot \mathrm{v}^{-1}$ maltol already reduced the degradation of DNA by approximately one order of magnitude, and concentrations $\geq 0.2 \% \mathrm{w} . \mathrm{v}^{-1}$ inhibited degradation completely. 
DNA degradation in food

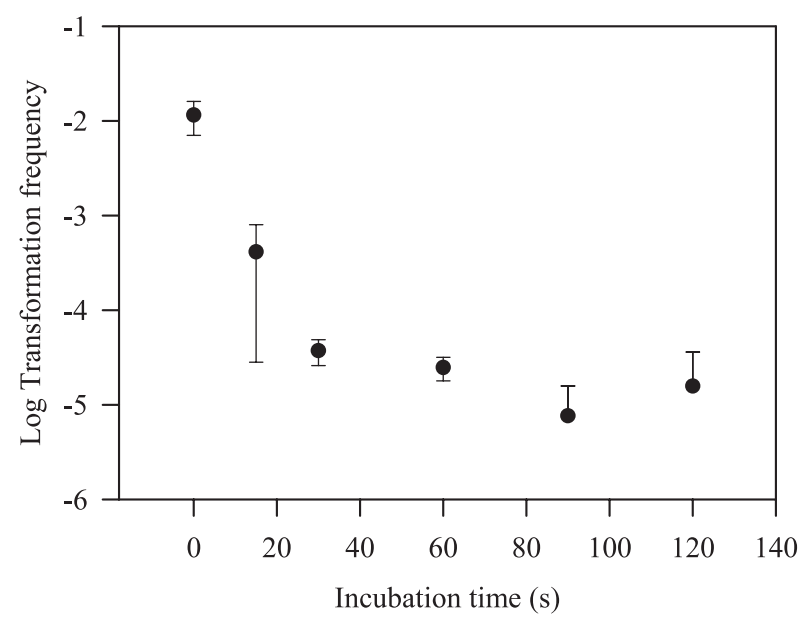

Figure 2. Degradation of plasmid DNA by DNase I monitored by determination of the transformation frequency (TF) using E. coli XL1 Blue. Error bars indicate standard deviations of at least 2 independent experiments.

Concentrations of $1 \mathrm{mM}$ putrescine reduced the degradation by approximately one order of magnitude, and concentrations of $0.01 \% \mathrm{~W} \cdot \mathrm{v}^{-1}$ of octyl gallate caused complete inhibition. As a control, DNA protection by spermine was used, and concentrations of $\geq 0.5 \mathrm{mM}$ inhibited DNA degradation completely.

\section{Effect of $\mathrm{pH}$ and temperature on the degradation of plasmid DNA}

During food processing, the matrix is subjected to major changes affecting the extractability of DNA and its concentration in the food. To monitor DNA degradation independently of processing and matrix effects, the following detection system was applied. Isolated DNA was subjected to real-time PCR, and the copy number of a large and small DNA fragment was determined by external calibration. As the likelihood of strand breaks increases with increasing length of DNA fragments, DNA degradation results in a reduced detectability of the large fragment compared to the small fragment (internal reference), which is also weakly degraded. Thus, the shift of ratio of the copy numbers of both fragments is correlated with the extent of DNA degradation.

To validate the applicability of this detection system, initial experiments were performed using plasmid DNA. DNA solutions were incubated at $85,90,95$ or $100{ }^{\circ} \mathrm{C}$ at various $\mathrm{pH}$ values up to $20 \mathrm{~min}$. Fragments of $846 \mathrm{bp}$ and $516 \mathrm{bp}$ were amplified and their copy number was determined. Plotting of the ratios revealed enhanced DNA degradation at increasing temperatures and decreasing $\mathrm{pH}$. Examples are depicted in Figure 3, showing the combined effect of temperature and $\mathrm{pH}$. No DNA degradation was observed at $85{ }^{\circ} \mathrm{C} / \mathrm{pH} 7$ (data not shown). These results demonstrated the applicability of the detection system. However, DNA degradation under harsh conditions (e.g. $100{ }^{\circ} \mathrm{C} / \mathrm{pH} 5.8$ ) can only be observed for a limited time span, since the sensitivity of the two DNA fragments to strand breaks is too high. This conclusion was reached by plotting the copy number of the 516 bp DNA fragments against the time of incubation at $100{ }^{\circ} \mathrm{C}$ (Fig. 4). At pH 6.0 the copy number decreased by approximately 6 orders of magnitude within $12 \mathrm{~min}$.

\section{Effect of food processing on the degradation of plant DNA}

To investigate the degradation of plant DNA during food processing, potato sticks, flakes and chips were produced under industrial conditions using the Apriori potato. For monitoring the extent of degradation, the ratio detection system was applied. Initial studies showed that all production processes led to strong DNA degradation, since DNA fragments of $719 \mathrm{bp}$ could no longer be amplified in the final products (data not shown). Thus, real-time PCR was used to amplify fragments of $325 \mathrm{bp}$ and 96 bp of the gbss gene, since reduction of the length of DNA fragment increases their detectability under harsh degradation conditions. The PCR systems were applied to DNA isolated from the various steps of processing. With regard to processing of potato sticks, it was observed that the drying step contributes most to the degradation of plant DNA (Fig. 5). Furthermore, in the course of chip and flake production, the plant DNA was strongly degraded by the heat treatment steps $\left(175{ }^{\circ} \mathrm{C} / 3 \mathrm{~min}\right.$ and $150{ }^{\circ} \mathrm{C} / 1 \mathrm{~min}$, respectively), and only DNA fragments of $96 \mathrm{bp}$ were amplified from the DNA isolated from the final products (data not shown). Because only small DNA fragments could be amplified, the ratio detection system could not be applied in these cases.

To investigate the effect of irradiation on DNA degradation in foods, potatoes as well as intermediate and final products of potato stick production were subjected to irradiation with doses of 10, 25 or $50 \mathrm{kGy}$. Again the ratio system could no longer be applied to all steps of processing, due to the failure in amplification of the 325 bp DNA fragment. Nevertheless, for sliced potatoes, a reduction of the ratio by 4.4-fold compared to the control was observed when a dose of $10 \mathrm{kGy}$ was applied. Increasing the dose only resulted in minor changes of the ratio, e.g. 5.7-fold for $50 \mathrm{kGy}$. 

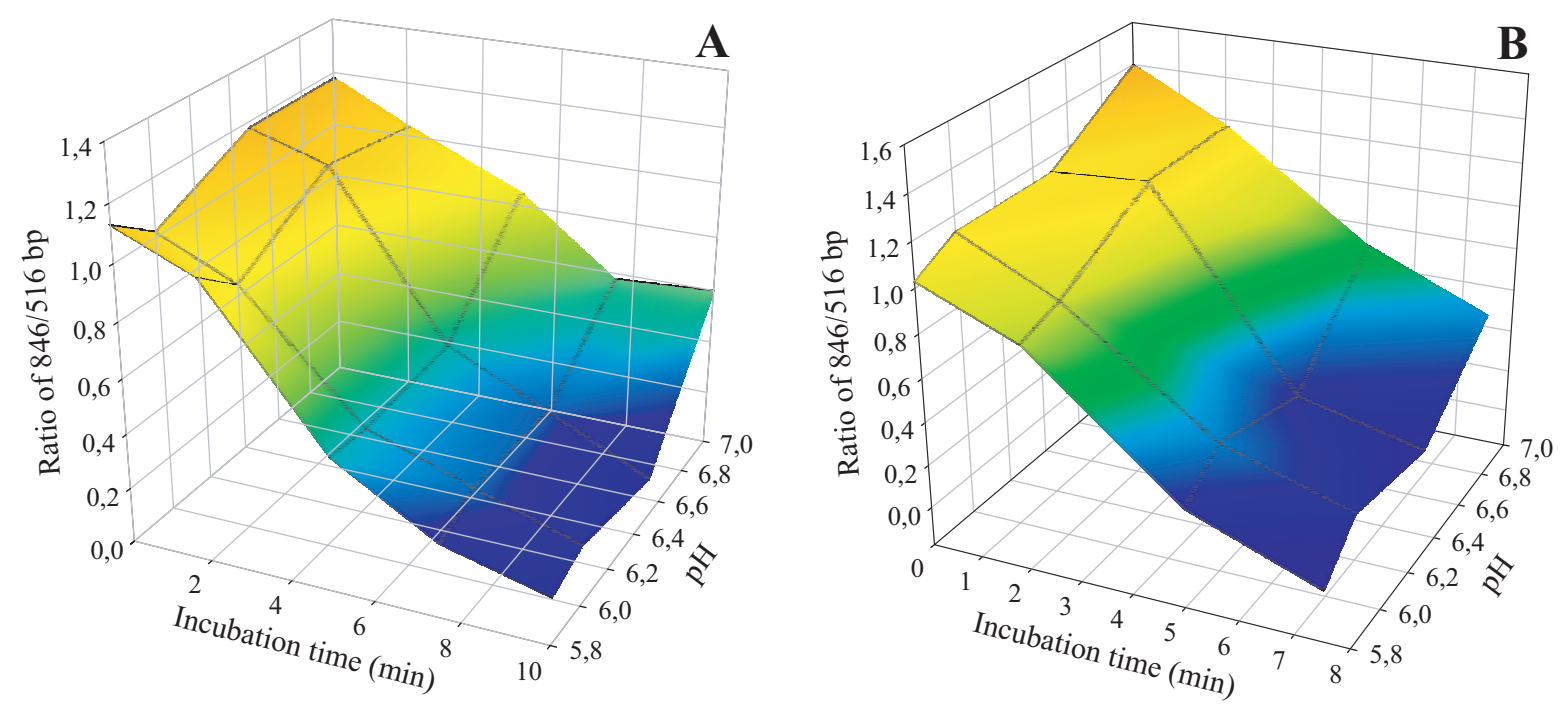

Figure 3. Effect of $\mathrm{pH}$ on degradation of plasmid DNA at $95^{\circ} \mathrm{C}(\mathrm{A})$ and $100{ }^{\circ} \mathrm{C}(\mathrm{B})$ monitored by real-time PCR. Copy numbers of 846 and 516 bp DNA fragments were determined and the ratios were plotted against incubation time and $\mathrm{pH}$.

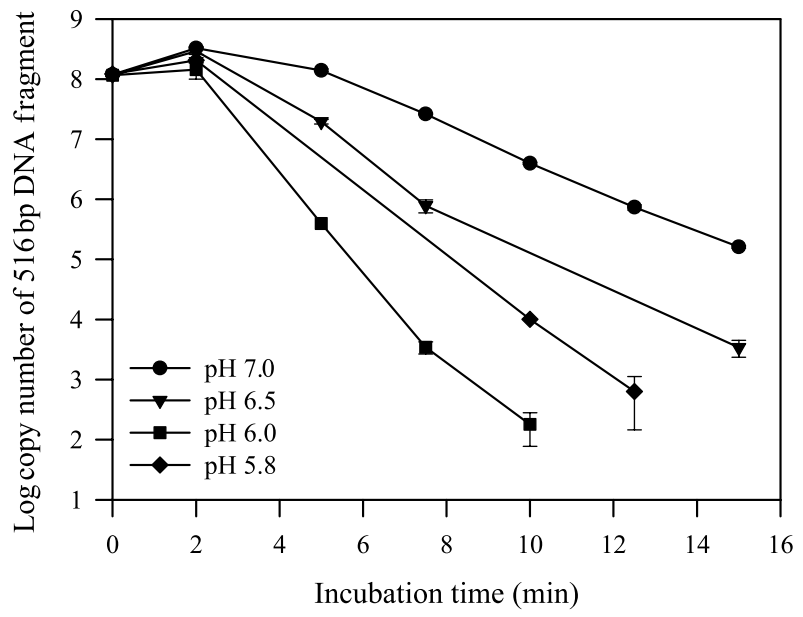

Figure 4. Degradation of the $516 \mathrm{bp}$ DNA fragment of plasmid pSG100 during incubation at $100{ }^{\circ} \mathrm{C}$ and various $\mathrm{pH}$ values. Copy numbers (mean value \pm standard deviation) were determined by triplicate real-time PCR analysis.

\section{DISCUSSION}

In this study, we developed novel approaches based on transformation and real-time PCR in order to measure the effect of food components and processing, respectively, on degradation of DNA in the complex environment, food. The transformation assay was designed to detect effects

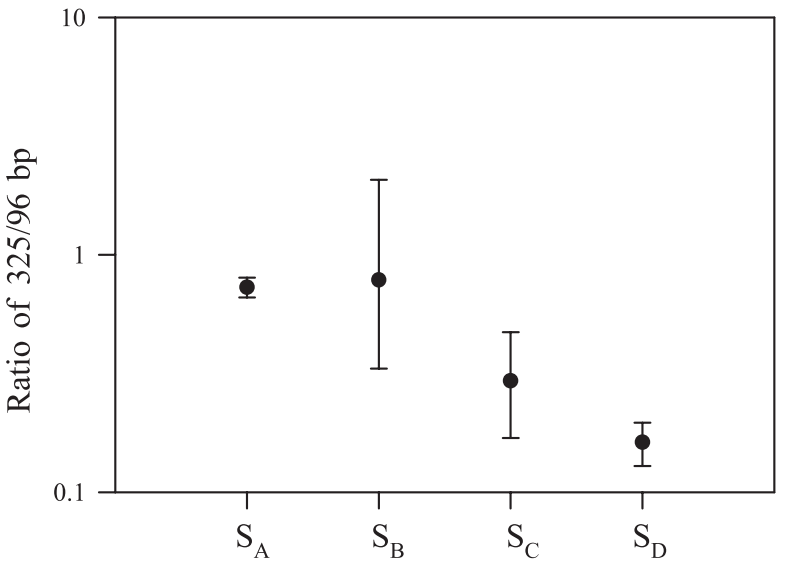

Figure 5. Degradation of plant DNA in the course of production of potato sticks monitored by real-time PCR. DNA was isolated from samples taken after slicing $\left(S_{A}\right)$, blanching $\left(S_{B}\right)$, drying for $2 \mathrm{~h}$ at $70{ }^{\circ} \mathrm{C}\left(S_{C}\right)$ and from the final product $\left(S_{D}\right)$. Mean values are depicted, and error bars indicate the limit of variation (for calculation see Materials and Methods).

of a single food component on DNA degradation by nucleases, one of the major degrading factors in food (Jonas et al., 2001). Use of this assay enabled us to obtain information on DNA molecules exceeding the simple detection of their presence, since only functional molecules that are capable to give rise to a transformed cell are monitored. In contrast to the use of a marker rescue 
system for monitoring the degradation of transgenic plant DNA (Kharazmi et al., 2003a); this assay has the advantage of following the kinetics of degradation over a wide range of DNA concentrations, and to perform the experiments under defined conditions, especially with regard to the time of incubation with DNase I. On the other hand, this assay does not consider potential differences in the degradation of plasmid and plant DNA molecules by DNase I.

We observed that none of the investigated food components affected the transformation efficiency of $E$. coli. In contrast to PCR-based methods, no DNA isolation or clean up was required, making the assay fast as well as reliable by reducing sources of errors. Remarkably, only 4 out of 29 representative food components exhibited a protective effect against enzymatic DNA degradation. Apparently the remaining components do not interact with the DNA and DNase I, or were applied in a concentration that is realistic with regard to foods but too low to cause effects. Maltol reduced the DNA degradation 10-fold at concentrations of $\geq 0.05 \%$, equal to $500 \mathrm{mg} \cdot \mathrm{kg}^{-1}$. It arises in situ during food processing due to Maillard reaction, and $e . g$. approximately $40 \mathrm{mg} . \mathrm{kg}^{-1}$ are naturally present in roasted coffee (Belitz and Grosch, 1992).

Octyl gallate (E 311) and other alkyl esters of gallic acid exhibit antioxidative properties and are used as food additives in amounts ranging from $0.01-0.02 \%$. We observed protective effects of octyl gallate at concentrations of $\geq 0.5 \mathrm{mM}$, equal to approximately $0.014 \%$. Recent results gave evidence for a negligible prooxidative property of octyl gallate in the presence of copper ions, which promote strand scission and formation of 8-hydroxy-2'deoxyguanosine (Yoshino et al., 2002). Similar properties were described earlier for tannic acid, a polymer form of gallic acid (Khan and Hadi, 1998; Khan et al., 2000). With regard to the stability of DNA, these ambivalent properties make octyl gallate a highly relevant molecule. The amines putrescine and spermine exhibited protective effects at concentrations of $\geq 1 \mathrm{mM}$ and $\geq 0.5 \mathrm{mM}$, equal to $0.09 \mathrm{~g} \cdot \mathrm{kg}^{-1}$ and $0.101 \mathrm{~g} . \mathrm{kg}^{-1}$, respectively. Spermine is a key component in the cell proliferation process (Heby, 1981), and when docked into the major groove of B-DNA, stabilizes the complex by maximizing interactions between proton acceptors on DNA and proton donors on spermine (Feuerstein et al., 1986). Deng et al. (2000) demonstrated the capability of spermine and spermidine to bind and condense B-DNA without disrupting the native structure. Condensation is thought to reduce the susceptibility of DNA against shear-induced degradation (Lengsfield and Anchordoquy, 2002) which can occur in food during processing. Putrescine and spermine are widely distributed in foods and occur in concentrations above the effective ones. In fresh pork and chicken meat, concentrations of only $2.7 \mathrm{mg} . \mathrm{kg}^{-1}$ were observed for putrescine (Bardócz et al., 1993). In fermented foods concentrations of putrescine of ca. 0.1-0.2 g. kg ${ }^{-1}$ in sauerkraut (Halasz et al., 1994), ca. 0.650 g. $\mathrm{kg}^{-1}$ in matured cheddar (Bardócz et al., 1993) and up to $3.5 \mathrm{~g} . \mathrm{kg}^{-1}$ in Maasdamer or Gouda (Halasz et al., 1994) were observed. Stute et al. (2002) determined the content of biogenic amines in 45 fish sauces from the Far East, and found up to $1.3 \mathrm{~g} \cdot \mathrm{kg}^{-1}$ putrescine.

Until now, DNA degradation caused by food processing had been investigated using PCR amplification. However, foods undergo major changes during processing, which alter the concentration of DNA and/or the extractability of DNA by e.g. formation of crosslinks due to Maillard reaction, starch gelatinisation or protein denaturation. Thus, the monitoring of DNA degradation by quantification of DNA molecules is hampered by variations in yield and quality of the extracted DNA. Our ratio detection systems made it possible to overcome these limitations and to monitor degradation of plant DNA during processing of dried potato sticks (Fig. 5). The failure of application of this system to potato flake and crisp production showed that the length of amplified fragments has to be adapted to the prevailing degradation conditions. Harsh conditions as applied during potato flake and crisp production would require the amplification of DNA fragments far below $300 \mathrm{bp}$. However, a difference in the fragment length of approximately $300 \mathrm{bp}$ was found to be suitable for successful application of the system (Fig. 3). Further reduction of this value would abolish differences in the degradation kinetics of DNA fragments due to similar sensitivity to the degrading factors, and changes of the ratio would become too small.

During processing of potatoes we identified heat treatment as a major parameter contributing to degradation of plant DNA. The potatoes were subjected to high temperatures (150 to $175{ }^{\circ} \mathrm{C}$ ) for short times (minutes), conditions that are commonly used in drying and frying processes. Until now, DNA degradation during food production was either monitored in processes run at temperatures up to $121{ }^{\circ} \mathrm{C}$ (Bauer et al., 2003; Gryson et al., 2002; Hupfer et al., 1998, 1999; Klein et al., 1998) or detected upon investigation of final products for reasons of traceability and labelling of GM food according to the European legislation (European Commission, 1997, 1998, 2000, 2003). For example, Klein et al. (1998) showed a reduction of plasmid DNA in the course of sugar production by three orders of magnitude during heat treatment at $121{ }^{\circ} \mathrm{C}$ for $30 \mathrm{~min}$. Taking into account the long exposure time, the DNA seems to be rather stable at this 
temperature. On the other hand, $121{ }^{\circ} \mathrm{C}$ is clearly below the extreme temperatures applied in potato crisp production. Intrinsic factors such as metal ions, $\mathrm{pH}$ or the formation of reactive intermediates during the heat treatment enhance the naturally occurring degradation of DNA (Lindahl, 1993). In addition, the matrix in which the free DNA is embedded plays an important role in DNA stability. For example, high persistence of bacterial DNA was observed in fermented summer sausages (Straub et al., 1999). The DNA can also be physically protected against nucleases when adsorbed to particles $e$.g. clay minerals (Demaneche et al., 2001).

In conclusion, under certain conditions, rapid degradation of DNA can occur during processing of foods. This degradation is affected by indigenous factors such as food components, $\mathrm{pH}$, nucleases, etc. and exogenous factors prevailing during processing and storage, which can act in a synergistic, antagonistic or additive way. Due to the huge variability of these factors in food and food production, it is obvious that the extent of DNA degradation cannot be predicted for a defined food product or processing step.

\section{MATERIALS AND METHODS}

\section{Bacterial strains, plasmid, potatoes and food components}

Plasmid pSG100 is a derivative of pUC18 (Norrander et al., 1983) containing the kanamycin resistance gene nptII (Beck et al., 1982). Escherichia coli JM109 (Yanisch- Perron et al., 1985) and XL1 Blue (Stratagene) were used as host for propagation of pSG100 and transformation experiments, respectively, and were grown in LB medium (Sambrook and Russel, 2001) at $37^{\circ} \mathrm{C}$. Selective media contained $100 \mu \mathrm{g} \cdot \mathrm{ml}^{-1}$ ampicillin. Electrocompetent cells of E. coli were prepared as described by Sambrook and Russel (2001). Genetically modified Solanum tuberosum cv. Apriori tubers were kindly provided by Avebe (The Netherlands). The following food components $\left(\% \mathrm{w} . \mathrm{v}^{-1}\right.$, if not indicated else) were used dissolved in Tris- $\mathrm{HCl}$ (10 mM, pH 8.4): Acesulfame K (0.5), adonitol (1), bovine serum albumin $\left(10,1,0.1 \mathrm{mg} \cdot \mathrm{ml}^{-1}\right)$, 3-tert-butyl-4-hydroxyanisole (0.5), carboxymethylcellulose (1), k-carrageenan (0.5), collagen (0.5), creatine (0.5), curcumin $(0.1)$, 4-hydroxybenzoic acid (0.5), myoinositol (1), lactic acid (1), lactose (1), D-mannitol (1), maltol $(2,1.5,1,0.5)$, sodium nitrate $(0.25)$, Patent blue V (0.1), phenylalanine (1), polyethylenimine $(1,0.5,0.1$, $0.05)$, putrescine $(100,10,1 \mathrm{mM})$, saccharin $(0.5)$, Simplesse $(1,0.5,0.1)$, sorbitol $(5,1)$, spermine $(50,5,0.5$,
$0.05 \mathrm{mM})$, tartrazine $(0.1)$, taurine $(0.5)$. The following food components were dissolved in ethanol/Tris $(50 / 50$, v/v): mono/di-glyceride (1), octyl gallate $(5,1,0.5,0.1)$, propyl gallate $(5,1)$, riboflavin (saturated).

\section{DNA isolations}

Plasmid DNA was isolated from over-night cultures using the Qiafilter Maxi Kit (Qiagen GmbH, Hilden, Germany) according to the manufacturer's instructions. DNA was eluted with Tris- $\mathrm{HCl}(10 \mathrm{mM}, \mathrm{pH} 8.4)$. The concentration of plasmid DNA solutions was determined as described by Berdal and Holst-Jensen (2001) and diluted to either $2.0 \times 10^{10}$ or $2.0 \times 10^{8}$ molecules. $\mu \mathrm{l}^{-1}$ and stored at $8{ }^{\circ} \mathrm{C}$. For extraction of genomic plant DNA, potato tubers or products were milled in a mortar with liquid nitrogen. DNA was isolated from $150 \mathrm{mg}$ of homogenized sample using the Nucleo-Spin Plant DNA extraction kit (Macherey-Nagel, Germany). The manufacturer's protocol was modified as follows: $800 \mu \mathrm{l}$ of buffer $\mathrm{C} 1$ and $10 \mu \mathrm{l}$ RNase A were added and incubated for $30 \mathrm{~min}$ at $37^{\circ} \mathrm{C}$ followed by $30 \mathrm{~min}$ at $60^{\circ} \mathrm{C}$. After centrifugation $\left(12000 \times g, 21^{\circ} \mathrm{C}, 5 \mathrm{~min}\right)$, the supernatant was transferred to a new cap and $800 \mu \mathrm{l}$ of buffer $\mathrm{C} 4$ as well as $600 \mu \mathrm{l}$ ethanol were added. The mixture was subjected to the column and centrifuged $\left(12000 \times g, 21^{\circ} \mathrm{C}, 1 \mathrm{~min}\right)$. DNA was washed with $400 \mu \mathrm{l}$ of buffer $\mathrm{CW}, 700 \mu \mathrm{l}$ of buffer $\mathrm{C} 5$ and once again with $200 \mu \mathrm{l}$ of buffer C5. DNA was eluted from the column with a total volume of $50 \mu$ l of buffer $\mathrm{CW}$ (preheated to $70^{\circ} \mathrm{C}$ ).

\section{Monitoring DNA degradation by transformation}

Dilutions of DNase I (EC 3.1.21.1, Invitrogen) were freshly prepared and adjusted to $0.5 \mathrm{U} . \mu \mathrm{l}^{-1}$. In a volume of $95 \mu \mathrm{l}, 10 \mu \mathrm{l}$ of the food component solution and $2 \times$ $10^{11}$ molecules of pSG100 were incubated in buffer ( $2 \mathrm{mM} \mathrm{MgCl}_{2}, 50 \mathrm{mM} \mathrm{KCl}, 20 \mathrm{mM}$ Tris- $\mathrm{HCl} \mathrm{pH} 8.4$ ) together with $5 \mathrm{U}$ of DNase I. The negative control was prepared without food component and DNase I. In the positive control only the food component was omitted. To exclude any effect of the food component on the transformation event itself, an additional control without DNase I but with the food component was performed. The mixture was incubated at $37^{\circ} \mathrm{C}$ for 2 min and degradation was stopped by addition of $\mathrm{Na}_{2}$ EDTA to a final concentration of $2.5 \mathrm{mM}$. An aliquot of $1 \mu \mathrm{l}$ was immediately used for electrotransformation of E. coli XL1 Blue, using a GenePulser Xcell (Bio-Rad) as described by Sambrook and Russel (2001). Total cell counts and counts of transformants were determined on 
LB medium and SOB containing $100 \mu \mathrm{g} \cdot \mathrm{ml}^{-1}$ ampicillin, respectively.

\section{Processing of Apriori potatoes}

Processing of Apriori potatoes to crisps, puree-powder (flakes) and dehydrated potato sticks was performed in the semi-technical facilities of the Federal Centre for Cereal, Potato and Lipid Research (BAGKF, Detmold, Germany) under conditions comparable to industrial production. For production of sticks, Apriori tubers were abrasive peeled, sliced to sticks of $24 \times 6 \times 6 \mathrm{~mm}^{3}$ and washed with cold tap water. Sticks were blanched for $150 \mathrm{~s}$ and washed to remove gelatinised starch. Drying of sticks was performed in two steps: $70{ }^{\circ} \mathrm{C}$ for $2 \mathrm{~h}$ followed by $50{ }^{\circ} \mathrm{C}$ for $2.5 \mathrm{~h}$. Samples were taken after slicing $\left(\mathrm{S}_{\mathrm{A}}\right)$, blanching $\left(\mathrm{S}_{\mathrm{B}}\right)$, drying step $I\left(S_{C}\right)$ and from the final product $\left(S_{D}\right)$. For production of flakes, tubers were abrasive peeled, sliced (10 mm thickness) and washed with cold tap water. Slices were heated to $70{ }^{\circ} \mathrm{C}$ for $20 \mathrm{~min}$ and conditioned at room temperature for $20 \mathrm{~min}$. Thereafter, they were cooked in a steam cooker for $20 \mathrm{~min}$, mashed and roll dried at $150{ }^{\circ} \mathrm{C}$ to obtain flakes. Alternatively, $5 \mathrm{~g}$ mono/di-glyceride (E 471) per kg potato were added to the cooked potatoes (during mashing), and flakes were produced as described above. Samples were taken after slicing $\left(\mathrm{F}_{\mathrm{A}}\right)$, cooking $\left(\mathrm{F}_{\mathrm{B}}\right)$ and from the final product without $\left(\mathrm{F}_{\mathrm{C}}\right)$ and with E $471\left(F_{D}\right)$. For production of crisps, tubers were abrasive peeled, sliced (1.2 mm thickness) and washed with cold tap water. Sliced tubers were further treated as follows: no blanching or blanched at (i) $80{ }^{\circ} \mathrm{C}$ in water for $1 \mathrm{~min}$, (ii) $80{ }^{\circ} \mathrm{C}$ in $0.25 \% \mathrm{NaHSO}_{3}$ for $1 \mathrm{~min}$, or (iii) $80{ }^{\circ} \mathrm{C}$ in $0.25 \% \mathrm{CaCl}_{2}$ for $1 \mathrm{~min}$. Finally, crisps were fried in peanut oil at $175{ }^{\circ} \mathrm{C}$ for $3 \mathrm{~min}$. Samples were taken after slicing $\left(\mathrm{C}_{\mathrm{A}}\right)$, blanching $\left(\mathrm{C}_{\mathrm{B}}\right)$ and after frying $\left(\mathrm{C}_{\mathrm{C}}\right)$.

In addition, the final products and all samples taken from the steps of potato stick production as well as frozen and thawed potatoes were irradiated with 10,25 or $50 \mathrm{kGy}$ in the facilities of the Federal Research Centre for Nutrition (BfE, Karlsruhe, Germany).

\section{Degradation of plasmid DNA by $\mathrm{pH}$ and heat treatment}

Stock solutions of $100 \mathrm{mM}$ BisTris (Sigma-Aldrich) were adjusted to $\mathrm{pH}$ 5.8, 6.0, 6.5 and 7.0 using $\mathrm{HCl}$. In a total volume of $100 \mu \mathrm{l}, 2.0 \times 10^{9}$ molecules of pSG100 were incubated in $10 \mathrm{mM}$ BisTris for 0-20 min at 85, 90, 95, and $100{ }^{\circ} \mathrm{C}$. After heat treatment the aliquots were cooled on ice and aliquots were immediately subjected to realtime PCR.

\section{Real-time PCR systems}

Real-time PCR amplifications with DNA of Apriori potato samples were carried out on an ABI 7000 Sequence detection system (Applied Biosystems). Primers GBSS-F1 (5'-TGTAGCTTGGTAGATTCCCCTTT-3'), GBSS-R1 (5'-CTAGTGAAGTTTGGCTTCTTGACA-3'), GBSS-R2 (5'-TTGCTCCAAGGACCAACCT-3'), and GBSS-R6 (5'-CTCCAAGAACATTGGGTGGT-3') targeting against the recombinant gbss (accession no. X83220) were constructed using Primer Express 2.0 software (Applied Biosystems) and Primer3 software (http://www.genome.wi.mit.edu/cgi-bin/primer/primer3_ www.cgi). The PCR mix $(30 \mu \mathrm{l})$ contained $1 \times \mathrm{SYBR}$ Green PCR Master mix (Applied Biosystems), $0.5 \mathrm{mM}$ of each primer, $4 \mathrm{mM} \mathrm{MgCl} 2,3 \mu \mathrm{g}$ BSA (Roche Diagnostics), and $5 \mu \mathrm{l}$ DNA solution. The thermal cycling program consisted of a preliminary incubation step of $2 \mathrm{~min}$ at $50{ }^{\circ} \mathrm{C}$ followed by an initial denaturation step at $95{ }^{\circ} \mathrm{C}$ for $10 \mathrm{~min}$ and 50 cycles of $95^{\circ} \mathrm{C}$ for $15 \mathrm{~s}, 60^{\circ} \mathrm{C}$ for $60 \mathrm{~s}$ and $72{ }^{\circ} \mathrm{C}$ for $60 \mathrm{~s}$. A melting curve analysis was performed starting at $60^{\circ} \mathrm{C}$. For amplification of PCR products of different length the following primer pairs were used: GBSS-F1/ GBSS-R1 (96 bp), GBSS-F1/GBSS-R2 (325 bp) and GBSS-F1/GBSS-R6 (719 bp). The ratio of concentrations of two DNA fragments was calculated using the mean values $\left(\overline{\mathrm{x}}_{325} \cdot \overline{\mathrm{x}}_{96}{ }^{-1}\right)$. The limit of variation was determined using the mean values $(\overline{\mathrm{x}})$ and corresponding standard deviations $(\mathrm{s})$ as follows: $\left(\overline{\mathrm{x}}_{325}+\mathrm{s}_{325}\right) \cdot\left(\overline{\mathrm{x}}_{96}-\mathrm{s}_{96}\right)^{-1}$ and $\left(\overline{\mathrm{x}}_{325}-\mathrm{s}_{325}\right) \cdot\left(\overline{\mathrm{x}}_{96}+\mathrm{s}_{96}\right)^{-1}$.

For amplification of DNA of pSG100, the primers described previously (Bauer et al., 2003) were used and amplification was performed as described above with the following modifications: pre-incubation at $50{ }^{\circ} \mathrm{C}$ for $2 \mathrm{~min}$ and initial denaturation at $95{ }^{\circ} \mathrm{C}$ for $10 \mathrm{~min}$, followed by 40 cycles of $95^{\circ} \mathrm{C}$ for $15 \mathrm{~s}, 52^{\circ} \mathrm{C}$ for $60 \mathrm{~s}$ and $72{ }^{\circ} \mathrm{C}$ for $120 \mathrm{~s}$. The following primer pairs were used: Fpri3/Rpri (516 bp) and pwlF/pwlR (846 bp).

\section{ACKNOWLEDGEMENTS}

We thank Elke Focken for excellent technical assistance. We are indebted to Dr. H. Schuchmann and employees for facilitating the irradiation of potato products at the Federal Research Centre for Nutrition. We thank AVEBE for supporting our studies by providing the transgenic Apriori potato. This work was supported by the European Community, project QLK1-1999-00527.

Received April 26, 2004; accepted December 20, 2004. 


\section{REFERENCES}

Bardócz S, Grant G, Brown DS, Ralph A, Pusztai A (1993) Polyamines in food-implications for growth and health. J. Nutr. Biochem. 4: 66-71

Bauer F, Hertel C, Hammes WP (1999) Transformation of Escherichia coli in foodstuffs. Syst. Appl. Microbiol. 22: 161168

Bauer T, Weller P, Hammes WP, Hertel C (2003) The effect of processing parameters on DNA degradation in food. Eur. Food Res. Technol. 217: 338-343

Beck E, Ludwig G, Auerswald EA, Reiss B, Schaller H (1982) Nucleotide sequence and exact localization of the neomycin phosphotransferase gene from transposon Tn5. Gene 19: 327-336

Belitz HD, Grosch W (1992) Lehrbuch der Lebensmittelchemie, Ed 4, Springer-Verlag, Berlin, Heidelberg, New York

Berdal KG, Holst-Jensen A (2001) Roundup Ready ${ }^{\circledR}$ soybean event-specific real-time quantitative PCR assay and estimation of the practical detection and quantification limits in GMO analyses. Eur. Food Res. Technol. 213: 432-438

Bräutigam M, Hertel C, Hammes WP (1997) Evidence for natural transformation of Bacillus subtilis in foodstuffs. FEMS Microbiol. Lett. 155: 93-98

Codex Alimentarius Commission (1999) Principles and guidelines for the conduct of microbiological risk assessment. CAC/GL-30.

ftp://ftp.fao.org/codex/standard/en/CXG_030e.pdf

Codex Alimentarius Commission (2003a) Report of the third session of the codex Ad Hoc intergovernmental task force on foods derived from biotechnology.

ftp://ftp.fao.org/codex/alinorm03/Al03_34e.pdf

Codex Alimentarius Commission (2003b) Guidelines for the conduct of food safety assessment of foods derived from recombinant-DNA plants. CAC/GL-45-2003.

ftp://ftp.fao.org/codex/2003Prepublicationtexts/

Codex_Texts_on_Biotechnology(E).pdf

de Vries J, Meier P, Wackernagel W (2001) The natural transformation of the soil bacteria Pseudomonas stutzeri and Acinetobacter sp. by transgenic plant DNA strictly depends on homologous sequences in the recipient cells. FEMS Microbiol. Lett. 195: 211-215

de Vries J, Wackernagel W (2002) Integration of foreign DNA during natural transformation of Acinetobacter sp. by homology-facilitated illegitimate recombination. Proc. Natl. Acad. Sci. USA 99: 2094-2099

Demaneche S, Jocteur-Monrozier L, Quiquampoix H, Simonet P (2001) Evaluation of biological and physical protection against nuclease degradation of clay-bound plasmid DNA. Appl. Environ. Microb. 67: 293-299

Deng H, Bloomfield VA, Benevides JM, George JT Jr (2000) Structural basis of polyamine-DNA recognition: spermidine and spermine interactions with genomic B-DNAs of different
GC content probed by Raman spectroscopy. Nucl. Acids Res. 17: 3379-3385

Douki T, Bretonniere Y, Cadet J (2000) Protection against radiation-induced degradation of DNA bases by polyamines. Radiat. Res. 153: 29-35

England LS, Holmes SB, Trevors JT (1998) Persistence of viruses and DNA in soil. World J. Microbiol. Biotechnol. 14: 163-169

European Commission (1997) Regulation No 258/97 of the European Parliament and of the Council of 27 January 1997 concerning novel foods and novel food ingredients. Official Journal of the European Communities L 043: 0001-0007. 14.02.1997

European Commission (1998) Council Regulation No 1139/ 98 of 26 May 1998 concerning the compulsory indication of the labelling of certain foodstuffs produced from genetically modified organisms of particulars other than those provided for in Directive 79/112/EEC. Official Journal of the European Communities L 159: 0004-0007. 03.06.1998

European Commission (2000) Regulation No 49/2000 of 10 January 2000 amending Council Regulation No 1139/98 concerning the compulsory indication on the labelling of certain foodstuffs produced from genetically modified organisms of particular or other than those provided for in Directive 79/112/EEC. Official Journal of the European Communities L 006: 0013-0014. 11.01.2000

European Commission (2003) Regulation No 1829/2003 of the European Parliament and of the Council of 22 September 2003 on genetically modified food and feed. Official Journal of the European Union L 268: 0001-0023. 18.10.2003

FAO/WHO (2000) Safety aspects of genetically modified foods of plant origin. Report of a joint FAO/WHO expert consultation on foods derived from biotechnology. http://www.who.int/foodsafety/publications/biotech/en/ ec_june2000_en.pdf

Feuerstein BG, Pattabiraman N, Marton LJ (1986) Spermine-DNA interactions: a theoretical study. Proc. Natl. Acad. Sci. USA 83: 5948-5952

Gebhard F, Smalla K (1998) Transformation of Acinetobacter sp. strain BD413 by transgenic sugar beet DNA. Appl. Environ. Microb. 64: 1550-1554

Gryson N, Ronsse F, Messens K, de Loose M, Verleyen T, Dewettinck K (2002) Detection of DNA during the refining of soybean oil. JAOCS 79: 171-174

Halasz A, Barath A, Simon-Sarkadi L, Holzapfel W (1994) Biogenic amines and their production by micro-organisms in food. Trends Food Sci. Tech. 5: 42-29

Heby O (1981) Role of polyamines in the control of cell proliferation and differentiation. Differentiation 19: 1-20

Hupfer C, Hotzel H, Sachse K, Engel KH (1998) Detection of the genetic modification in heat-treated products of $\mathrm{Bt}$ maize by polymerase chain reaction. Z. Lebensm. Unters. Forsch. 206: 203-207 
DNA degradation in food

Hupfer C, Mayer J, Hotzel H, Sachse K, Engel KH (1999) The effect of ensiling on PCR-based defection of genetically modified Bt maize. Eur. Food Res. Technol. 209: 301-304

Jonas DA, Elmadfa I, Engel KH, Heller KJ, Kozianowski G, König A, Müller D, Narbonne JF, Wackernagel W, Kleiner J (2001) Safety considerations of DNA in food. Ann. Nutr. Metab. 45: 235-254

Khan NS, Hadi SM (1998) Structural features of tannic acid important for DNA degradation in the presence of $\mathrm{Cu}(\mathrm{II})$. Mutagenesis 13: 271-274

Khan NS, Ahmad AS, Hadi SM (2000) Anti-oxidant, prooxidant properties of tannic acid and its binding to DNA. Chem.-Biol. Interact. 125: 177-189

Kharazmi M, Hammes WP, Hertel C (2002) Construction of a marker rescue system in Bacillus subtilis for detection of horizontal gene transfer in food. Syst. Appl. Microbiol. 25: 471-7

Kharazmi M, Bauer T, Hammes WP, Hertel C (2003a) Effect of food processing on the fate of DNA with regard to degradation and transformation capability in Bacillus subtilis. Syst. Appl. Microbiol. 26: 495-501

Kharazmi M, Sczesny S, Blaut M, Hammes WP, Hertel C (2003b) Marker rescue studies of the transfer of recombinant DNA to Streptococcus gordonii in vitro, in foods and gnotobiotic rats. Appl. Environ. Microbiol. 69: 61216127

Klein J, Altenbuchner J, Mattes R (1998) Nucleic acid and protein elimination during the sugar manufacturing process of conventional and transgenic sugar beets. J. Biotechnol. 60: $145-153$

Lammerding AM (1997) An overview of microbial food safety risk assessment. J. Food. Prot. 60: 1420-1425

Lengsfeld CS, Anchordoquy TJ (2002) Shear-induced degradation of plasmid DNA. J. Pharm. Sci. 91: 15811589
Lindahl T (1993) Instability and decay of the primary structure of DNA. Nature 362: 709-715

Norrander J, Kempe T, Messing J (1983) Construction of improved M13 vectors using oligodeoxynucleotide- directed mutagenesis. Gene 26: 101-106

Oh TJ, Kim IG (1998) Polyamines protect against DNA strand breaks and aid cell survival against irradiation in Escherichia coli. Biotechnol. Tech. 12: 755-758

Rizzi A, Panebianco L, Giaccu D, Sorlini C, Daffonichio D (2003) Stability and recovery of maize DNA during food processing. Ital. J. Food Sci. 15: 499-510

Sambrook J, Russel DW (2001) Molecular Cloning: a laboratory manual, Ed 3. CSHL Press, Cold Spring Harbour, New York

Straub JA, Hertel C, Hammes WP (1999) The fate of recombinant DNA in thermally treated fermented sausages. Z. Lebensm. Unters Forsch. 210: 62-67

Stute R, Petridis K, Steinhart H, Biernoth G (2002) Biogenic amines in fish and soy sauces. Eur. Food Res. Technol. 215: 101-107

Wittke A, Lick S, Heller KJ (2002) Transformation of Bacillus subtilis in chocolate milk: evidence for low frequency of establishment of cells transformed under nonselective conditions. Syst. Appl. Microbiol. 25: 478-482

Yanisch-Perron C, Vieira J, Messing J (1985) Improved M13 phage cloning vectors and host strains: nucleotide sequences of the M13mp18 and pUC19 vectors. Gene 33: 103-119

Yoshino M, Haneda M, Naruse M, Htay HH, Iwata S, Tsubouchi R, Murakami K (2002) Prooxidant action of gallic acid compounds: copper-dependent strand breaks and the formation of 8-hydroxy-2'-deoxyguanosine in DNA. Toxicol. in vitro 16: 705-709

Zenz KI, Neve H, Geis A, Heller KJ (1998) Bacillus subtilis develops competence for uptake of plasmid DNA when growing in milk products. Syst. Appl. Microbiol. 21: 28-32 